\title{
The Energy Boom: Boon or Bane for Local Philanthropy?
}

Hyunseok Hwang*

Department of Sociology

4351 TAMU

Texas A \& M University

gustjr2002@tamu.edu

p: (979) 820-1074

*corresponding author

Laurie E. Paarlberg

Professor of Philanthropic Studies and Charles Stewart Mott Chair on Community Foundations

IU Lilly Family School of Philanthropy

IUPUI

Email: 1paarlbe@indiana.edu

This is the author's manuscript of the article published in final edited form as:

Hwang, H., \& Paarlberg, L. E. (2019). The Energy Boom: Boon or Bane for Local Philanthropy? Social Science Quarterly, 100(5), 1899-1915. https://doi.org/10.1111/ssqu.12682 


\begin{abstract}
Objective. This article explores the complex relationships between the energy boom, economic and demographic, and local philanthropy. This study aims to find direct effects of the energy boom and indirect effects of multiple mediators, community economic conditions, population change, racial diversity, and income inequality, on local philanthropy.

Methods. Drawing upon data from U.S. counties, a series of mediation analyses are tested by following Baron and Kenney (1986)'s causal-steps procedures.

Results. The energy boom always has negative direct effects on local philanthropy. Although indirect effects of mediators are not always significant, total effects, as the sum of direct and indirect effects, reveal that income, population growth, and racial diversity positively mediates negative effects of the energy boom on local philanthropy. The energy boom increases levels of income inequality; however, increased income inequality paradoxically is positively associated with local philanthropy.

Conclusion. The relationship among the energy boom, community economic and demographic conditions, and local philanthropy is complex. Although direct effects of the energy boom are negative, key findings of positive indirect effects suggest implications for policymakers, nonprofit practitioners, and community leaders when dealing with grand societal challenges caused by natural resource development at the community level.
\end{abstract}

Keywords: Local philanthropy, energy boom, economic inequality 


\section{INTRODUCTION}

The recent strong shale oil and gas production has changed the landscape of local communities as advanced hydraulic fracturing technology has enabled mass extraction from shale deposits, dramatically affecting local economies of natural resource-rich regions (Brown, Dorins, and Krannich, 2005; Lawries, Tonts, and Plummer, 2011). At the local level, shale oil and gas producing communities have experienced rapid economic growth with income increases, higher employment rates, and increased local government revenues (Bartik et al., 2016). It is expected that an increase in energy production affects the levels of human and financial resources in local communities. The large-scale resource development is a double-edged sword for local communities because it reaps economic benefits while causing local societal challenges such as environmental pollution, high crime rates, and income inequality (Bartik et al., 2016). Communities that have been through large-scale natural resource development are more likely to experience social disruption due to rapid social changes, which declines the quality of life and levels of social cohesion (Brasier et al., 2011; Smith, Krannich, and Hunter, 2001).

Although the economic, environmental, and social changes that accompany natural resource development have received a fair amount of attention, little is known about how a boom in resource extraction affects local philanthropy. A strong relationship between local economic conditions and local philanthropy is saliently supported by the existing literature (Bekkers and Wiepking 2007; 2010). Philanthropy - charitable giving of time and money for the public purpose - is considered as an outcome or indicator of community social cohesion (Barman 2017; Brennan, Paarlberg, and Hoyman 2013; Paxton 1999). Local philanthropy largely depends on a supply of human and financial resources and requires a collective awareness of community issues, and constituents' willingness to support the redistribution of resources. Local 
philanthropy is not only the sum of the individual philanthropic behaviors, but it also reflects a collective expression of civic generosity and responsibility in response to community needs and issues (Paarlberg and Yoshioka, 2016 ; Wolpert, 1988). Accordingly, since philanthropy is more than a function of collective resources, it entails a reflection of the propensity of a community to support collective issues.

Drawing upon the social context of the recent shale oil and gas boom, this study aims to demonstrate how the energy boom affects local philanthropy through local socioeconomic conditions and community income and racial heterogeneity as summarized in figure 1. We test a series of empirical models at the U.S. county level in two time periods (2003 and 2014) using data obtained from the National Center for Charitable Statistics (NCCS) and the U.S. Census's American Community Survey (ACS). We begin with reviewing the literature on the determinants of local philanthropy. Since little is known about how the energy boom indirectly affects philanthropy through local economic and social structures our empirical findings are expected to contribute to providing a better understanding of these complex relationships by proposing implications for policymakers and nonprofit practitioners.

[Figure 1 a summary of relationships about here]

\section{LITERATURE REVIEW}

Nonprofit scholars have suggested that place-based propensities for philanthropy are produced by historical and regional values transmitted by religious and cultural patterns of development (Schneider, 1996). These values influence regional patterns of political ideology and attitudes toward government and philanthropy. On the one hand, the local economic structure with financial capacity does not only affect local philanthropy, but collective 
willingness of the community to resolve local needs also shapes local philanthropy by mobilizing community resources as an institutionalized form of collective action (Paarlberg and Yoshioka, 2016; Paarlberg, Hoyman, and McCall, 2018). In particular, natural resources industries, which follow boom and bust cycles, may significantly dampen local philanthropy as local resource extraction corporations and their employees are more likely to feel less long-term connection to the community. When such corporations are not locally owned, there may be even less commitment to the needs of the local community (Heying, 1997).

\section{H1: The energy boom has a direct negative impact on local philanthropy}

An important driver of philanthropic activity in a place is access to financial resources, and the energy boom is expected to support increased philanthropy through economic development. However, studies of the energy boom in the 1970s and 1980s indicate large-scale resource development disrupted communities by creating social problems through rapid economic and demographic changes (Freudenburg, 1992; Freudenburg, William, and Wilson, 2002). After the 1980s, studies provide mixed evidence on social disruption and socioeconomic well-being in energy boom communities (Smith, Krannich, and Hunter, 2001). For instance, in energy boom communities of Pennsylvania, New York, and North Dakota, civic engagement at public meetings increased as community members concerned with environmental issues became more active in civic affairs (Theodori, 2013).

Research found that shale deposits in local communities positively affect the economic growth in cases of Texas, Wyoming, and Colorado with positive impacts of an increase in energy production on local economic growth (Weber, 2012). Effects of an increase in the energy production on the local economy are supported by the stable rise of the total employment rate compared to other non-energy producing states (Christopherson, 2011). In other oil and gas 
producing states such as Pennsylvania and West Virginia, the drilling in shale deposits created job opportunities and business activity (Brasier et al., 2011). In the state of Ohio, the average sales receipts and employment growth rates were higher in strong shale oil and gas producing counties than the state average in 2012 (Kinahan and Hill, 2013).

We posit that the oil and gas production affect local philanthropy through income increases. In energy boomtowns, transitioning from agricultural to extractive industries creates job opportunities and increases community financial resources for individuals, organizations, and the local government (Freudenburg, 1992). Wealthy communities are more likely to have higher employment rates. Philanthropic endeavor is supported by community financial resources (Hwang and Young, 2019). Based on the existing literature, it is hypothesized that local economic conditions positively transmit the energy boom to local philanthropy.

H2a: The energy boom has a direct positive impact on median household income of the community.

H2b: The energy boom will indirectly increase local philanthropy through higher median household income of the community.

Improved community socioeconomic conditions may attract populations that seek employment opportunities. Urban areas with effects of neighborhood poverty experience depopulation. Depopulated urban areas can be deinstitutionalized due to a lack of social infrastructures. (Small, Manduca, and Johnston, 2018) The outflux of poor urban populations reach to disrupted, but transiently booming communities to economically better off. The social cohesion that facilitates local philanthropy is shaped by local structure of networks. However, transient populations are less likely to be embedded in local networks that strengthen ties among 
neighborhoods. Communities with the high level of social cohesion seek to balance between internal and external ties to build community capacity for shared goals and values (Sharkey, Torrats-Espinosa, and Takyar, 2017). In this line of reasoning, energy boom communities highly depend on external sources of influence and resources. Therefore, we posit that the energy boom may lead to the influx of populations; however, population growth is likely to dampen local philanthropy.

H3a: The energy boom has a direct positive affect on population growth.

H3b: The energy boom will indirectly decrease local philanthropy through population growth

The influx of employees working in fields of the extractive industry are more likely to increase community diversity as experienced in Marcellus shale deposits (Lichter, 2012; Weber 2012) However, according to constrict theory (Putnam, 2007), community heterogeneity dampens levels of social cohesion because people are less likely to interact with people from different social or racial groups (McPherson, Smith-Lovin, and Cook, 2001) which declines social capital in heterogeneous communities (Paarlberg, Hoyman, and McCall, 2018; Putnam, 2007). There is some evidence that racial diversity is negatively associated with secular volunteer rates (Rotolo and Wilson, 2014) and donations (Andreoni et al., 2016). We posit that the energy boom increases levels of community racial diversity, which dampens local philanthropy.

H4a: The energy boom has a direct positive affect on community racial diversity.

H4b: The energy boom will indirectly decrease local philanthropy through increased racial diversity. 
Portes and Vickstrom (2011) argue income inequality also erodes levels of social integration.

Income inequality, the unequal distribution of economic resources, reduces social solidarity and causes greater competition for resources (McCausland and Theodossiou, 2013). Rapid economic growth in a community, particularly a largely rural community, may accentuate levels of income inequality. We, therefore, expect that the energy boom will dampen philanthropy by increasing income inequality.

H5a: The energy boom has a direct positive affect on levels of community income inequality.

H5b: The energy boom will indirectly decrease local philanthropy through income inequality.

\section{DATA AND METHOD}

Our empirical models use a series of regression analyses to test how the energy boom affects local philanthropy through socioeconomic conditions and community heterogeneity. This analysis relies on the causal-steps procedures of pathway mediation analysis based on a series of Ordinary Least Squares (OLS) regression models ${ }^{1}$ (Aguinis et al., 2005; Aguinis and Gottfredson, 2010; Baron and Kenny, 1986). The unit of analysis is U.S. counties. The data is obtained from National Center for Charitable Statistics (NCCS), the U.S. Census², United States Department of Agriculture (USDA), and Bureau of Economic Analysis (BEA). Statistical models are tested at two points in 2003 as a supplementary analysis for a reference model (before

\footnotetext{
${ }^{1}$ We conducted a mediation analysis with Stata/SE 14.2 Coefficients of direct and indirect effects are estimated by paramed command that computes direct and indirect effects. Coefficients of direct and indirect effects are estimated by evaluating the role of mediators (Valeri and VanderWeele, 2013).

${ }^{2}$ The data in 2013 was obtained from Census Bureau's American Community Survey's five year estimate (2008-2013). The data in 2002 was obtained from Census Bureau's USA counties data file downloads that include Small Area Income Population Estimate (SAIPE). The source is downloaded from https://www.census.gov/support/USACdataDownloads.html
} 
the shale oil and gas boom) and 2014 as the main analysis (right after the shale oil and gas boom). Our analysis employs a cross-sectional analysis exploring differences across place instead of employing time-series and cross sectional analysis because changes in energy production during a given time are employed as antecedents to estimate mediating effects of the local economy and community heterogeneity on local philanthropy ${ }^{3}$. To alleviate a concern regarding an endogeneity issue of reverse or simultaneous causality, independent, mediating, and control variables are lagged for 1 year in the main analysis and 1 and 3 years in the supplementary analysis while following the causal-steps procedures of mediation analysis (Baron and Kenny, 1986; Bascle, 2008; Certo et al., 2016) ${ }^{4}$. Variance Inflation Factors (VIFs) on two baseline models in 2003 and 2014 are below 1.5, which suggests limited multicollinearity issue. Table 1 shows operationalization, transformation, and sources of all variables for regression analyses.

[Table 1 Data overview here]

\section{VARIABLES}

\footnotetext{
${ }^{3}$ In considering the nature of mediation analysis, our method draws the pathway analysis using four mediators that explain how the energy boom is related to local philanthropy as a causal relationship. Our partial mediation analysis must meet three conditions: 1) X (an independent variable) relates to $\mathrm{Y}$ (a dependent variable), 2) $\mathrm{X}$ relates to $\mathrm{M}$ (a mediator), and 3) $\mathrm{M}$ relates to $\mathrm{Y}$ when controlling for $\mathrm{X}$, and this mediation relationship is effective when using the causal steps approach with cross-sectional analysis for temporal precedence rather than longitudinal analysis (MacKinnonet al., 2002; Mathieu and Taylor, 2006).

${ }^{4}$ Besides a causal or simultaneous causality, endogeneity occurs for a number of different reasons. Endogeneity with unobserved or omitted variables occurs when independent variables are correlated with the error term in empirical models. A robustness check reveals that error terms in all models are zerocorrelated with independent, mediating and control variables, which resolves a concern regarding potential endogeneity with omitted variables (Bascle, 2008).
} 
Dependent Variable. The dependent variable, local philanthropy, is measured as per capita monetary contributions to local nonprofit organizations. These monetary contributions include all types of contributions from individuals and foundations as reported on the Internal Revenue Service (IRS) 990 tax reports. All 501(c)3 for tax-exempt on nonprofit organizations are required to report their finances to the IRS. The data are available in the National Center for Charitable Statistics (NCCS) Core Files. In 2014, nonprofit organizations with less than $\$ 50,000$ in annual revenue are not required to file a 990 form to IRS, but in 2003, nonprofit organizations with more than $\$ 25,000$ were required to file a 990 form. Our dependent variable is a per capita measure of the sum of monetary contributions to nonprofit organizations nested in counties (Beaton and Hwang, 2017; Paarlberg and Hwang, 2017).

Mediating variables. We use four mediating variables: 1) median household income, 2) population growth 3) community racial diversity, and 4) income inequality. First, we measure community income with county's median household income. Second, population growth is calculated as below.

$$
\left(\frac{\text { The total population in } 2013-\text { the total population in } 2000}{\text { The total population in } 2013}\right)
$$

Third, to measure community racial diversity, we employ the racial diversity index. The Census Bureau provides the following races or ethnicity categories: 1) Hispanic or Latino, 2) NonHispanic White, 3) Non-Hispanic Black or African American, 4) Non-Hispanic Asian, 5) NonHispanic American Indians and Alaskan Native, 6) Non-Hispanic other races. In the general race or ethnicity categories, the Census Bureau classifies Hispanic or Latino populations as White. In the category of Non-Hispanic, the Census Bureau distinguishes between White and Hispanic or 
Latino population. A Gini-Simpson index is employed to measure community racial diversity index as the equation indicates below (Paarlberg, Hoyman, and McCall, 2018).

$$
\text { Gini-Simpson Index }=1-\sum_{\mathrm{n}=1}^{m}(n / N)_{i}^{2}
$$

Where $n$ is the proportion of each race or ethnicity's population in $N$, the total population, in each county. In the study, $i$ signifies six racial groups. The value of the index ranges between 0 and 1; 0 represents no diversity and 1 represents infinite diversity. Fourth, we obtained a measure income inequality with the Gini coefficient in the unit of analysis (county). Values the Gini coefficient close to 1 indicate that a county has maximum income inequality (one person holds all the income); values close to 0 indicate that a county is purely equal (everyone has the same income).

Independent variable: All counties are classified into three categories: strong oil and gas producing counties, weak oil and gas producing counties, and non-oil and gas producing counties. Categorical variables are employed to estimate precise coefficients than artificial or continuous mediating variables (Aguinis and Gottfresdon, 2010). Two independent variables are employed separately in oil and gas production in the analysis of 2014. For oil and gas production change, observations are coded as 2 if the oil or gas production has increased from 2000 to 2011. Observations are coded as 1 if oil or gas production has decreased during the observation time period. Observations coded as 0 are non-oil or -gas producing counties. To compare the pre-shale boom level in the reference year of 2003, a binary variable is employed whether counties produced oil and gas at that time.

Control Variables. The model includes two control variables: 1) the density of nonprofit organizations and 2) urbanity. The density of nonprofit organizations indicates existing levels of 
nonprofit capacity and a local demand for nonprofit resources. Urbanity, whether counties are urban or rural, is a binary variable coded as 1 if the population is over 50,000 . This aligns with how the Census classifies urbanity. Community resources and needs vary across the size of counties (Sharkey, Torrats-Espinosa, and Takyar, 2017). Table 2 presents the summary of descriptive statistics in the given year of analysis.

[Table 2 The summary of descriptive statistics about here]

\section{RESULTS}

\section{Findings and analysis}

To test our model, we use mediation analysis. Mediation analysis explains a relationship bewteen independent variables (oil and gas production) and a dependent variable (local philanthropy) by testing how mediators (income, population change, racial diversity, and income inequality) transmit the effects of independent variables (gas and oil production) on a dependent variable. As Baron and Kenny (1986) emphasize that partial mediation analysis can be expressed in in terms of the three regression equations shown in the following.

$$
\begin{aligned}
& Y=b_{0}+b_{1} E \\
& M(\text { Income })=b_{0}+b_{3} \text { Energy } \\
& M(\text { Population change })=b_{0}+b_{3} \text { Energy } \\
& M(\text { Racial diversity })=b_{0}+b_{3} \text { Energy } \\
& M(\text { Income inequality })=b_{0}+b_{3} \text { Energy }
\end{aligned}
$$




$$
\begin{aligned}
Y= & b_{0}+b_{5} \text { Income }+b_{6} \text { Population change }+b_{6} \text { Racial diversity }+ \\
& b_{7} \text { Income inequality }+b_{3} \text { Energy }
\end{aligned}
$$

Table 3 presents the results of multiple regression analyses. Model 1-5 tests for the direct effects of oil production change on local philanthropy and report negative effects $(-63.86, p<0.05)$. In table 4, model 2-5 also reports that change in gas production change has a negative effect on local philanthropy $(-68.15, p<0.05)$. These findings support hypothesis 1 .

[Table 3 Mediation analysis of regression in 2014: oil production change about here]

[Table 4 Mediation analysis of regression in 2014: gas production change about here]

Median household income. In table 3, model 1-1 indicates that change in oil production has direct positive effects on income. Although the effect is not significant $(0.333, p>0.1)$, median household income has direct positive effects on local philanthropy in model 1-5 (13.06, $p<0$. 01). In table 4, model 2-1 shows that gas production change has no significant effect on income $(0.0176, p>0.1)$, and in model $2-5$, income directly affects the growth in local philanthropy $(12.94, p<0.01)$. In figure 2, despite positive but not significant indirect effects of median household income, the significant total effects (A-B / a-b) are negative and significant (oil: 59.501, $p<0.05$ / gas: $-67.919, p<0.05)$. Hypotheses $2 \mathrm{a}$ and $2 \mathrm{~b}$ are not fully supported by our findings because findings reveal non-significant indirect effects. However, results partially support hypotheses with the total effects indicating that the negative effects of energy production change on local philanthropy are mitigated by median household income. 
Population change. In table 3 and 4, although increases in oil and gas production negatively affects population change $(-0.0164, p<0.01 ;-0.00958, p<0.01)$, the effect of population change on philanthropy is negative but not significant $(-156.3, p>0.1 ;-138.1, p>0.1)$. These results do not fully support hypothesis H3a. In figure 2, the significant total effects (A-C / a-c) are still significant and negative (oil: $-61.293, p<0.05$ / gas: $-66.823, p<0.05$ ). The total effects indicate that the negative effects of energy production change on local philanthropy are mitigated by population change.

Community racial diversity (racial heterogeneity). Contrary to hypothesis $4 \mathrm{a}$ and $4 \mathrm{~b}$, the energy boom does not have significant direct effects on racial diversity (oil model 1-3: 0.00308, p>0.1 / gas model 2-3: 0.00347, $\mathrm{p}>0.1$ ), but community racial diversity by itself positively and significantly affects local philanthropy (oil model 1-5: 580.0, $\mathrm{p}<0.01$ / gas model 2-5: 580.7, $\mathrm{p}<0.01)$. Although the indirect effect through community racial diversity is not significant, the total effects (A-D / a-d) are significant and negative (oil: -62.071, $p<0.05$ / gas: $-66.133, p$ $<0.05$ ) as displayed in figure 2 . In interpreting the total effects, negative effects of energy production changes are also mitigated by community racial diversity.

Income inequality (economic heterogeneity). Consistent with hypotheses $5 \mathrm{a}$ and $5 \mathrm{~b}$, the energy boom increases levels of income inequality. In table 3, model 1-4 indicates that oil production change has a positive effect on Gini coefficients $(0.00251, p<0.01)$, and in model $1-5$, the Gini coefficient is positively associated with local philanthropy $(6,750, p<0.01)$. In table 4 , model $2-4$ shows that the change in gas production has direct positive effect on the Gini coefficient 
$(0.00272, p<0.01)$, and in model $2-5$, the Gini coefficient positively affects local philanthropy $(6,765, p<0.01)$. In figure 2 , the marginally significant total effects (A-E / a-e) are still negative (oil: $-46.926, p<0.1$ / gas: $-49.776, p<0.1$ ). However, income inequality reduces the direct negative effects of energy production change on local philanthropy.

[Figure 2 Summary of relationships during the energy boom about here]

\section{Supplementary analysis}

To compare our results during the energy boom period with analyses in pre-shale boom time, we conducted additional mediation analyses, and figure 3 shows direct and indirect effects of the energy-producing status on local philanthropy in 2003. Consistent with results during the energy boom, oil and gas production in the community has negative effects on local philanthropy. However, unlike models in 2014, results show negative indirect effects of median household income that does not positively mediate an independent variable on local philanthropy, which means that the energy-producing status did not increase the income level during the pre-shale boom. Although mediating indirect effects of income variable are not significant, the total negative effects are escalated by mediating effects of income. On the other hand, racial diversity and income inequality as mediators have positive indirect effects on local philanthropy. Unlike insignificant indirect effects of community racial diversity in 2014, indirect effects of community racial diversity on local philanthropy are significantly positive. In consistent with results in 2014 , the energy producing status negatively affects local philanthropy by increasing levels of income inequality.

[Figure 3 Summary of relationship in the pre-shale boom about here] 


\section{DISCUSSION AND CONCLUSION}

Our findings suggest complex relationships among the economic structure (referring to the energy boom), community socioeconomic and demographic characteristics, and local philanthropy. The main finding is consistent with the existing literature that natural resource development influences collective action (Brown, Dorius, and Krannich, 2005; Collier and Hoeffler, 2005). Regardless of time periods, energy production consistently has negative direct effect on local philanthropy, which indicates a decline in social integration, trust, the propensity for collective action (Smith, Krannich, and Hunter, 2001). The energy boom with technological advances of hydraulic fracturing in shale deposits reduces local philanthropy of the institutionalized form of collective action. While the energy boom seems like the bonanza for economic growth at first glance, the effects of resource discovery are evanescent.

Our analysis suggests that that the energy boom has the negative impacts on local philanthropy through the income increase as shown with the total effects in figure 2 . This finding implies that the recent shale oil and gas booms have had more positive than previous conventional energy booms, but do not have significant impacts on increasing community income. In the early energy boom era, mining and extraction industries actually were able to lead to the emergence of economic prosperity with job opportunities and sales activities at the community level (Freudenburg, 1992; Kinahan and Hill, 2013). Improving socioeconomic conditions is expected to provide some communities the ability to buffer the external shocks associated with lack of community commitment. However, our results reveal that the income increase is less likely to be significantly influenced by the energy boom, and the influx of population is less likely to occur because the energy boom in shale deposits does not require massive labors like traditional extraction industries. Oil and gas deposits, especially shale, are 
located in less populous areas that lack of social and economic infrastructures can be exploited by external corporations that legitimize corporate capitalism and dampen social cohesion (Roth et al., 2018).

In this analysis, findings suggest the energy production change does not have significant direct effects on community racial diversity. However, a community racial diversity has direct and positive effects on local philanthropy as shown in the total effects. This finding implies that the negative effects of energy boom on local philanthropy are mitigated by promoting community racial diversity. The direct effects were hypothesized because the existing literature regarding the energy boom found a positive relationship between the occurrence of demographic heterogeneity and philanthropic activities (Brown, Dorins, and Krannich, 2005; Hwang and Young, 2019). Rural sociological literature found that social integration is eroded by large influxes of newcomers and population growth caused by the energy booms (Lichter, 2012). However, the mediation analysis in results of pre-shale boom period as a supplementary analysis suggests that negative effects of the energy-producing status on local philanthropy are offset through community racial diversity because community racial diversity is often considered collective resource when playing a role as the vehicle in connecting the social fabric (Berry, 2011).

As hypothesized, the energy boom significantly escalates income inequality; however, increased income inequality is positively associated with local philanthropy. Some scholars argue that philanthropy is not associated with reducing income inequality, but conversely, it increases levels of income inequality (Beaton and Hwang, 2018; Marquis, Davis, and Glynn, 2013). Our findings reveal that income inequality is positively associated with high levels of local philanthropy. As the wealth rises in a community, energy field entrepreneurs become 
important community philanthropists (Ostrower, 1997). Theses entrepreneurial philanthropists are more likely to support corporate foundations and elite-oriented organizations that preserve corporate legitimacy and upper-class values rather than community-oriented nonprofit organizations that seek to resolve social problems caused by extracting corporations (Marquis, Davis, and Gylnn, 2013; Roth et al., 2018). Findings suggest that further exploration of recipients of contributions may help to understand this relationship as elites are more likely contribute to elite philanthropy (Berrone et al., 2016), which can explain a positive relationship between income inequality and philanthropy.

Although the extractive industry in shale deposits seems mostly responsible for community social problems such as increased income inequality and environmental challenges, energy corporations are less likely to invest in local philanthropy. Transient as well as evanescent energy boom disrupts the community ecology and weaken social cohesion whereas exploitive external corporations only economically benefit, which is ultimately detrimental to local philanthropy. The classic idea suggests that the density of large corporations is positively associated with the low level of income inequality because the corporate employment produces the local income increase (Davis and Cobb, 2010). However, external corporations in natural resource industries exploit community resources, but avoid social responsibilities while conducting corporation wrongdoing, which increases local income inequality as a result of the imbalance between internal and external dependence. Community oriented organizations are more likely to be committed to community needs and focus less on exploiting profitmaximization (Almandoz, 2014). However, energy corporations are not often locally owned but operate the energy production in the nation or state wide. Therefore, energy corporations that reap economic benefits from local communities might be less interested in community social 
problems such as income inequality, education, and environmental issues, which dampens local philanthropy.

Our findings suggest policy implications for nonprofit practitioners, local policymakers, and corporate managers. Due to a transition from market efficiency in New Public Management to democratic collaboration in New Public Governance (Hammerschmid and Meyer, 2005; Polzer et al., 2016), community stakeholders need to collaboratively resolve social problems caused by disruptive technologies of hydraulic fracturing corporations. Despite a presence of Corporate Social Responsibility (CSR) programs, the view of CSR dysfunctions has largely been established because CSRs prioritize to legitimize corporate capitalism rather than criticizing their wrongdoing and challenging social problems (Fleming and Jones, 2013). In this line of interpretation, our results imply that exploitive external corporations that fracture the shale energy worsen local income inequality as the main cause of declining socioeconomic conditions and community wellbeing.

Nonprofit organizations and municipal governments are required to challenge income inequality problem by balancing internal and external resource dependence (Pfeffer and Salancik, 2003). In addition, in the face of drastic social and social changes (Adger, 2000) that accompany economic development, local policymakers and nonprofit practitioners are recommended to collaboratively implement local policies to build the social fabric of the community, including social cohesion and local philanthropy. Since many energy boomtowns have experienced social disruption that dampens levels of local philanthropy, community social learning might allow innovative social policies or nonprofit program implementations that reduce direct negative effects of the energy boom on local philanthropy (Adger, 2000). Our study does not address the increased need for services that may result from economic development, 
increased diversity and income inequality. However, our findings propose that local leaders are required to address collective social problems challenged by natural resource development.

This study has some limitations. First, future analyses need to move beyond crosssectional analyses and examine changes over time in all units of analysis to fully address the causal mechanism between energy production change and community factors. The use of panel data, and time-series data are recommended for comprehensive analysis. Second, this study focuses on local philanthropy as a dependent variable. Additional indicators of social disruption, such as crime rate, poverty, social capital should be explored. Third, we do not directly explore why oil and gas production dampens philanthropy, and this will passively be developed by further field work. Notwithstanding, our findings conceptually extend existing models of philanthropy that connect economic structure and social and economic resources with local philanthropy. While philanthropic values are rooted in long-standing cultural shared norms, values and beliefs, philanthropy is also quite responsive to social and economic changes as a result of changing community characteristics and the direct effects of the energy boom on local philanthropy.

Our findings of mediation analyses contribute to the literature by suggesting how one form of economic disruption, the energy boom, directly and indirectly, influences local philanthropy. The findings from the unique social context offer a caution to social science scholars who explore the complex community determinants of philanthropy and community leaders who increasingly rely upon philanthropy to address public issues. Finally, our study addresses an emphasis on much-needed problem-driven research to explore solutions for grand societal challenges that have massive social, economic, and environmental problems at cross levels. Energy production is beneficial to the public; however, it also produces byproducts of 
addressed social problems. Although social problems currently remain at the community level, it is possible transcend barriers of local communities (George et al., 2016). Local philanthropy as an institutionalized form of philanthropic collective action can mobilize community resources for collaborative models to prevent grand societal challenges caused by massive energy production (Hwang and Young, 2019). 


\section{REFERENCES}

Adger, W.N., 2000. "Social and ecological resilience: are they related?" Progress in human geography 24(3): 347-364.

Almandoz, Juan. 2014. "Founding teams as carriers of competing logics: When institutional forces predict banks' risk exposure." Administrative Science Quarterly 59(3): 442-473.

Aguinis, H., J.C. Beaty, R.J. Boik, and C.A. Pierce. 2005. "Effect size and power in assessing moderating effects of categorical variables using multiple regression: a 30-year review." Journal of Applied Psychology 90(1): 94.

Aguinis, H., R.K. Gottfredson, and T.A. Wright. 2011. "Best-practice recommendations for estimating interaction effects using meta-analysis." Journal of Organizational Behavior 32(8): 1033-1043.

Andreoni, J., A. Payne., J. Smith, and D. Karp. 2016. "Diversity and donations: The effect of religious and ethnic diversity on charitable giving." Journal of Economic Behavior \& Organization 128: 47-58.

Bascle, Guilhem. 2008. "Controlling for endogeneity with instrumental variables in strategic management research." Strategic organization 6(3): 285-327.

Baron, R.M. and D.A. Kenny, 1986. "The moderator-mediator variable distinction in social psychological research: Conceptual, strategic, and statistical considerations." Journal of personality and social psychology 51(6): 1173.

Bartik, A.W.,J. Currie, M. Greenstone, and C.R. Knittel, 2016. "The local economic and welfare consequences of hydraulic fracturing."

Barman, Emily. 2017. "The Social Bases of Philanthropy." Annual Review of Sociology 43(1):271-90. Retrieved (http://www.annualreviews.org/doi/10.1146/annurev-soc-060116053524).

Beaton, Erynn. E. and Hyunseok Hwang. 2017. "Increasing the Size of the Pie: The Impact of Crowding on Nonprofit Sector Resources." Nonprofit Policy Forum 8(3): 211-235.

Beaton, Erynn. E. and Hyunseok Hwang, 2018. "The Role of Philanthropy in Reproducing Inequality" Academy of Management Proceedings.

Bekkers, René and Pamala Wiepking. 2007. "Philanthropy: A Literature Review." 1-67.

Berrone, Pascual, Liliana Gelabert, Federica Massa-Saluzzo, and Horacio E. Rousseau. 2016. "Understanding community dynamics in the study of grand challenges: How nonprofits, institutional actors, and the community fabric interact to influence income inequality." Academy of Management Journal 59(6): 1940-1964.

Berry, John W. 2011. "Integration and multiculturalism: Ways towards social solidarity." Papers on Social Representations 20(1): 2-1.

Boddie, S.C., 2002. "Fruitful partnerships in a rural African American community: Important lessons for faith-based initiatives." The Journal of Applied Behavioral Science 38(3): 317333. 
Brasier, K.J., M.R. Filteau, D.K. McLaughlin, J. Jacquet, R.C. Stedman, T.W. Kelsey, and S.J. Goetz, 2011. "Residents' Perceptions of Community and Environmental Impacts from Development of Natural Gas in the Mcellus Shale: A Comparison of Pennsylvania and New York Cases." Journal of Rural Social Sciences, 26(1): 32.

Brennan, John F., Laurie Paarlberg, and Michele Hoyman. 2013. "Assembling the Puzzle of the Nonprofit-Economic Development Linkage." Nonprofit Policy Forum 5(1). Retrieved (https://www.degruyter.com/view/j/npf.2014.5.issue-1/npf-2012-0016/npf-2012-0016.xml).

Brown, R.B., S.F. Dorins, and R.S. Krannich, 2005. "The boom-bust-recovery cycle: dynamics of change in community satisfaction and social integration in Delta, Utah." Rural Sociology, 70(1): 28-49.

Christopherson, S., 2011. "The economic consequences of Marcellus shale gas extraction: Key issues."

Collier, P. and A. Hoeffler. 2005. "Resource rents, governance, and conflict." Journal of conflict resolution 49(4): 625-633.

Cooper, D., W.D. McCausland, and I. Theodossiou. 2013. "Income inequality and wellbeing: The plight of the poor and the curse of permanent inequality." Journal of economic issues 47(4): 939-958.

Cronbach, L.J. and R.J. Shavelson. 2004. "My current thoughts on coefficient alpha and successor procedures." Educational and psychological measurement, 64(3): 391-418.

Davis, Gerald F., and J. Adam Cobb. 2010. "Corporations and economic inequality around the world: The paradox of hierarchy." Research in Organizational Behavior 30: 35-53.

Fleming, P. and M. T. Jones. 2013. The end of corporate social responsibility: Crisis and critique. Thousand Oaks, CA: Sage Publications

Freudenburg, W.R., 1992. "Addictive economies: Extractive industries and vulnerable localities in a changing world economy." Rural Sociology, 57(3): 305-332.

Freudenburg, William R. and Lisa J. Wilson. 2002. "Mining the Data: Analyzing the Economic Implications of Mining for Nonmetropolitan Regions.” Sociological Inquiry 72(4):549-75.

George, Gerard, Jennifer Howard-Grenville, Aparna Joshi, and Laszlo Tihanyi. 2016. "Understanding and tackling societal grand challenges through management research." Academy of Management Journal 59(6): 1880-1895.

Greco, L.M., E.H. O'Boyle, B.S. Cockburn, and Z. Yuan. Forthcoming. "Meta-Analysis of Coefficient Alpha: A Reliability Generalization Study." Journal of Management Studies.

Hammerschmid, Gerhard, and Renate E. Meyer. 2005. "New public management in Austria: local variation on a global theme?." Public Administration 83(3): 709-733.

Heying, C.H., 1997. "Civic elites and corporate delocalization: An alternative explanation for declining civic engagement." American Behavioral Scientist, 40(5), pp.657-668.

Hoyman, Michele, Jamie McCall, Laurie Paarlberg, and John Brennan. 2016. "Considering the Role of Social Capital for Economic Development Outcomes in U.S. Counties." Economic 
Development Quarterly 30(4):342-57.

Hwang, Hyunseok, and Tiffany Amorette Young. 2019. "Considering the effectiveness of philanthropic collective action: a community ecology perspective." International Journal of Sociology and Social Policy ahead-of-print 39(3/4): 201-220.

Hwang, Hyunseok, and Tiffany Amorette Young. 2019. "How does community philanthropy function?: Direct effects of the social problem and the moderating role of community racial diversity." The Social Science Journal.

Kinahan, K. and E.W. Hill. 2013. Ohio Utica Shale Region Monitor.

Lichter, Daniel T. 2012. "Immigration and the new racial diversity in rural America." Rural Sociology 77(1): 3-35.

Lawrie, M., M. Tonts, and P. Plummer. 2011. "Boomtowns, resource dependence and socioeconomic well-being." Australian Geographer 42(2): 139-164.

MacKinnon, David P., Chondra M. Lockwood, Jeanne M. Hoffman, Stephen G. West, and Virgil Sheets. 2002. "A comparison of methods to test mediation and other intervening variable effects." Psychological methods 7(1): 83.

Marchand, Joseph. 2012. "Local Labor Market Impacts of Energy Boom-Bust-Boom in Western Canada." Journal of Urban Economics 71(1):165-74. Retrieved (http://dx.doi.org/10.1016/j.jue.2011.06.001).

Marquis, C., G.F. Davis, and M.A. Glynn. 2013. "Golfing alone? Corporations, elites, and nonprofit growth in 100 American communities." Organization Science 24(1): 39-57.

Mathieu, John E., and Scott R. Taylor. 2006. "Clarifying conditions and decision points for mediational type inferences in organizational behavior." Journal of Organizational Behavior: The International Journal of Industrial, Occupational and Organizational Psychology and Behavior 27(8): 1031-1056.

McCarthy, John D. and Mayer N. Zald. 1977. "Resource Mobilization and Social Movements: A Partial Theory." American Journal of Sociology 82(6):1212-41. Retrieved (http://www.journals.uchicago.edu/doi/10.1086/226464).

McPherson, M., L. Smith-Lovin, and J.M. Cook. 2001. "Birds of a feather: Homophily in social networks." Annual review of sociology 27(1): 415-444.

Ostrower, F. 1997. Why the wealthy give: The culture of elite philanthropy. Princeton University Press.

Paarlberg, L.E. and T. Yoshioka. 2016. "The impact of local economic structure on community philanthropy." Public Administration Review 76(2): 340-350.

Paarlberg, Laurie E., Michele Hoyman, and Jamie McCall. 2018. "Heterogeneity, income inequality, and social capital: a new perspective." Social Science Quarterly 99(2): 699-710.

Paarlberg, Laurie E., and Hyunseok Hwang. 2017. "The heterogeneity of competitive forces: the impact of competition for resources on united way fundraising." Nonprofit and Voluntary Sector Quarterly 46(5): 897-921. 
Paxton, Pamela. 1999. "Is Social Capital Declining in the United States? A Multiple Indicator Assessment." American Journal of Sociology 105(1):88-127. Retrieved (http://www.journals.uchicago.edu/doi/10.1086/210268).

Pfeffer, Jeffrey, and Gerald R. Salancik. 2003. The external control of organizations: A resource dependence perspective. Stanford, CA: Stanford University Press.

Polzer, T., R. E. Meyer, M. A. Höllerer, and J. Seiwald. 2016. "Institutional Hybridity in Public Sector Reform: Replacement, Blending, or Layering of Administrative Paradigms." In How Institutions Matter! Edited by Gehman, J., M. Lounsbury, and R. Greenwood., pp. 69-99. Bingley, UK: Emerald Group Publishing Limited.

Portes, Alejandro and Erik Vickstrom. 2011. "Diversity, Social Capital, and Cohesion.” Annual Review of Sociology 37(1):461-79. Retrieved (http://www.annualreviews.org/doi/10.1146/annurev-soc-081309-150022).

Putnam, R.D., 2007. "E pluribus unum: Diversity and community in the twenty-first century the 2006 Johan Skytte Prize Lecture." Scandinavian political studies 30(2): 137-174.

Roth, Steffen, Vladislav Valentinov, Markus Heidingsfelder, and Miguel Pérez-Valls. 2018. "CSR Beyond Economy and Society: A Post-capitalist Approach." Journal of Business Ethics 1-13.

Rotolo, T. and J. Wilson. 2012. "State-level differences in volunteerism in the United States: Research based on demographic, institutional, and cultural macrolevel theories." Nonprofit and Voluntary Sector Quarterly 41(3): 452-473.

Rotolo, Thomas and John Wilson. 2014. "Social Heterogeneity and Volunteering in U.S. Cities." Sociological Forum 29(2):429-52.

Schervish, Paul G., Mary A. O’Herlihy, and John J. Havens. 2001. "Agent Animated Wealth and Philanthropy: The Dynamics of Accumulation and Allocation among High Tech Donors."

Schneider, J. C. 1996. "Philanthropic styles in the United States: Toward a theory of regional differences." Nonprofit and Voluntary Sector Quarterly, 25(2), 190-210.

Sharkey, P., G. Torrats-Espinosa, and D. Takyar. 2017. "Community and the Crime Decline: The Causal Effect of Local Nonprofits on Violent Crime." American Sociological Review 82(6): 1214-1240.

Small, M. L., R. A. Manduca, and W. R. Johnston. 2018. "Ethnography, Neighborhood Effects, and the Rising Heterogeneity of Poor Neighborhoods across Cities." City \& Community 17(3): 565-589.

Simons, Daniel J. 2012. "Musings on Writing." (1):8. Retrieved (http://www.dansimons.com/resources/writing_tips.html).

Smith, M.D., R.S. Krannich, and L.M. Hunter, 2001. "Growth, decline, stability, and disruption: A longitudinal analysis of social Well-Being in four western rural communities." Rural Sociology 66(3): 425-450.

Theodori, G.L. 2013. "Perception of the natural gas industry and engagement in individual civic 
actions." Journal of Rural Social Sciences 28(2): 22.

Tolbert II, Charles M. 2005. "Minding Our Own Business: Local Retail Establishments and the Future of Southern Civic Community." Social Forcces 83(4):1309-28.

Uslaner, Eric M. and Mitchell Brown. 2005. "Inequality, Trust, and Civic Engagement." American Politics Research 33(6):868-94.

Valeri, L., and T. J. VanderWeele. 2013. "Mediation analysis allowing for exposure-mediator interactions and causal interpretation: Theoretical assumptions and implementation with SAS and SPSS macros." Psychological methods 18(2): 137

Weber, Jeremy G. 2012. "The Effects of a Natural Gas Boom on Employment and Income in Colorado, Texas, and Wyoming." Energy Economics 34(5):1580-88. Retrieved (http://dx.doi.org/10.1016/j.eneco.2011.11.013).

Wolpert, Julian. 1988. "The Geography of Generosity: Metropolitan Disparities in Donations and Support for Amenities." Annals of the Association of American Geographers 78(4):665-79. 


\section{FIGURES}

Figure 1. A causal effect of energy on local philanthropy through mediators

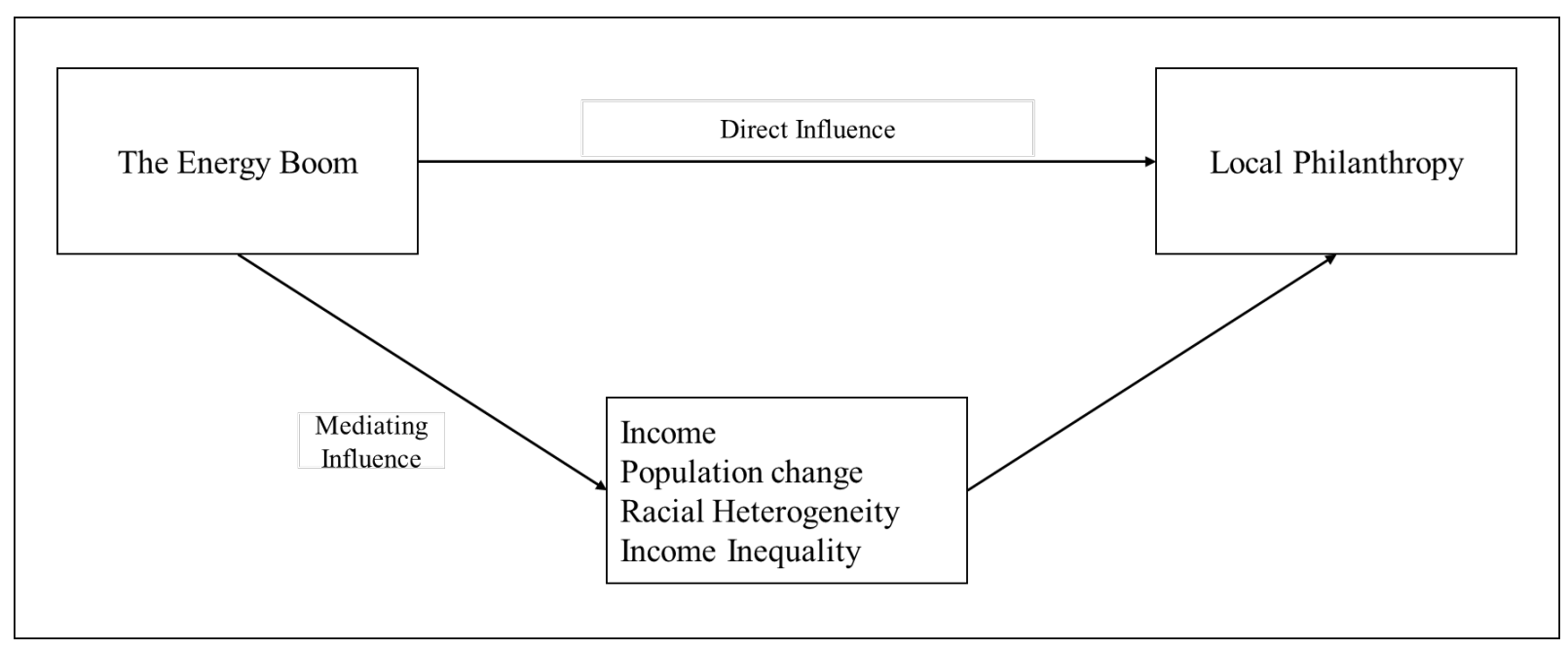


Figure 2 Summary of relationship during the energy boom

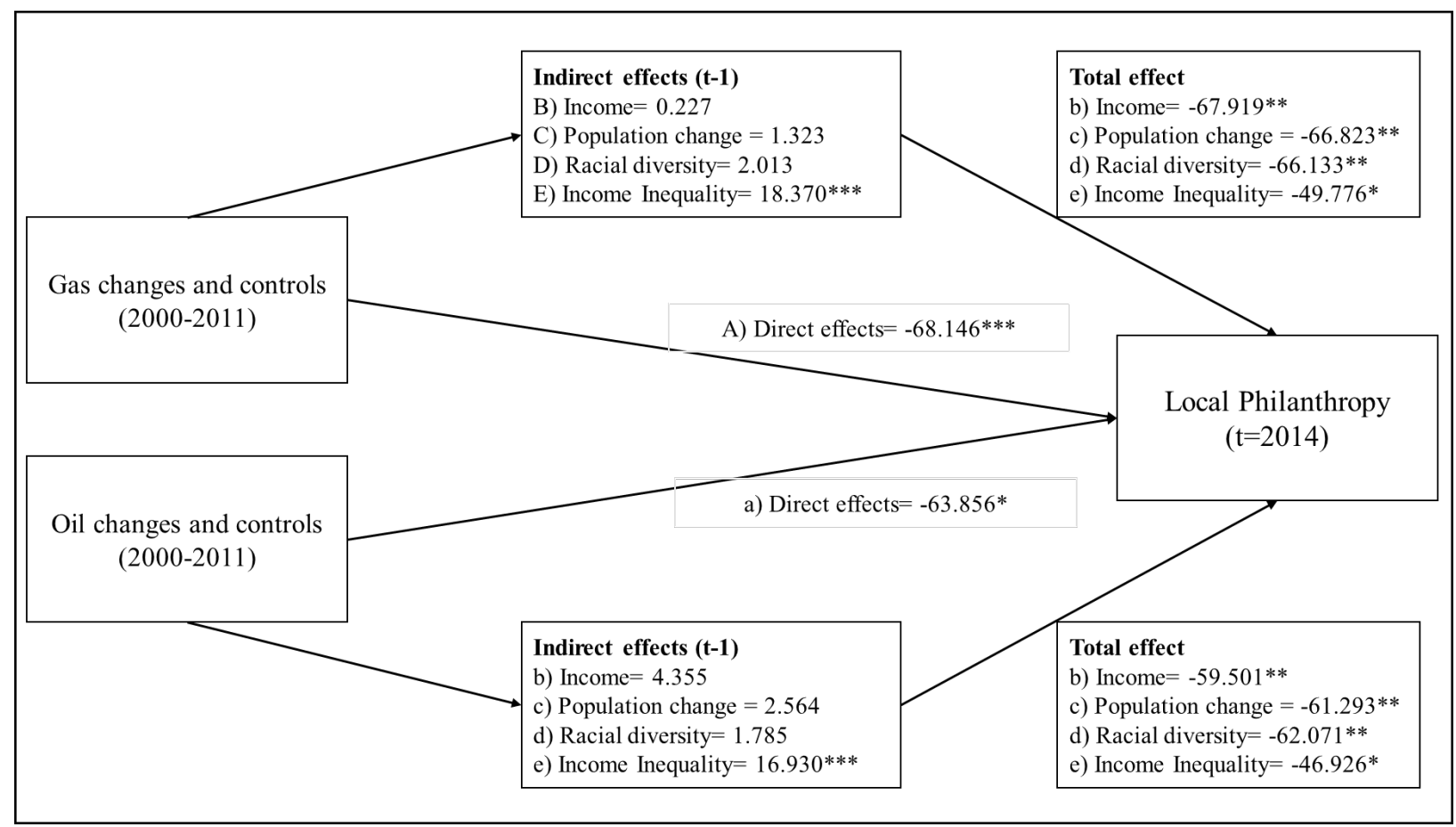

Figure 3 Summary of relationship in the pre-shale boom (as a supplementary analysis)

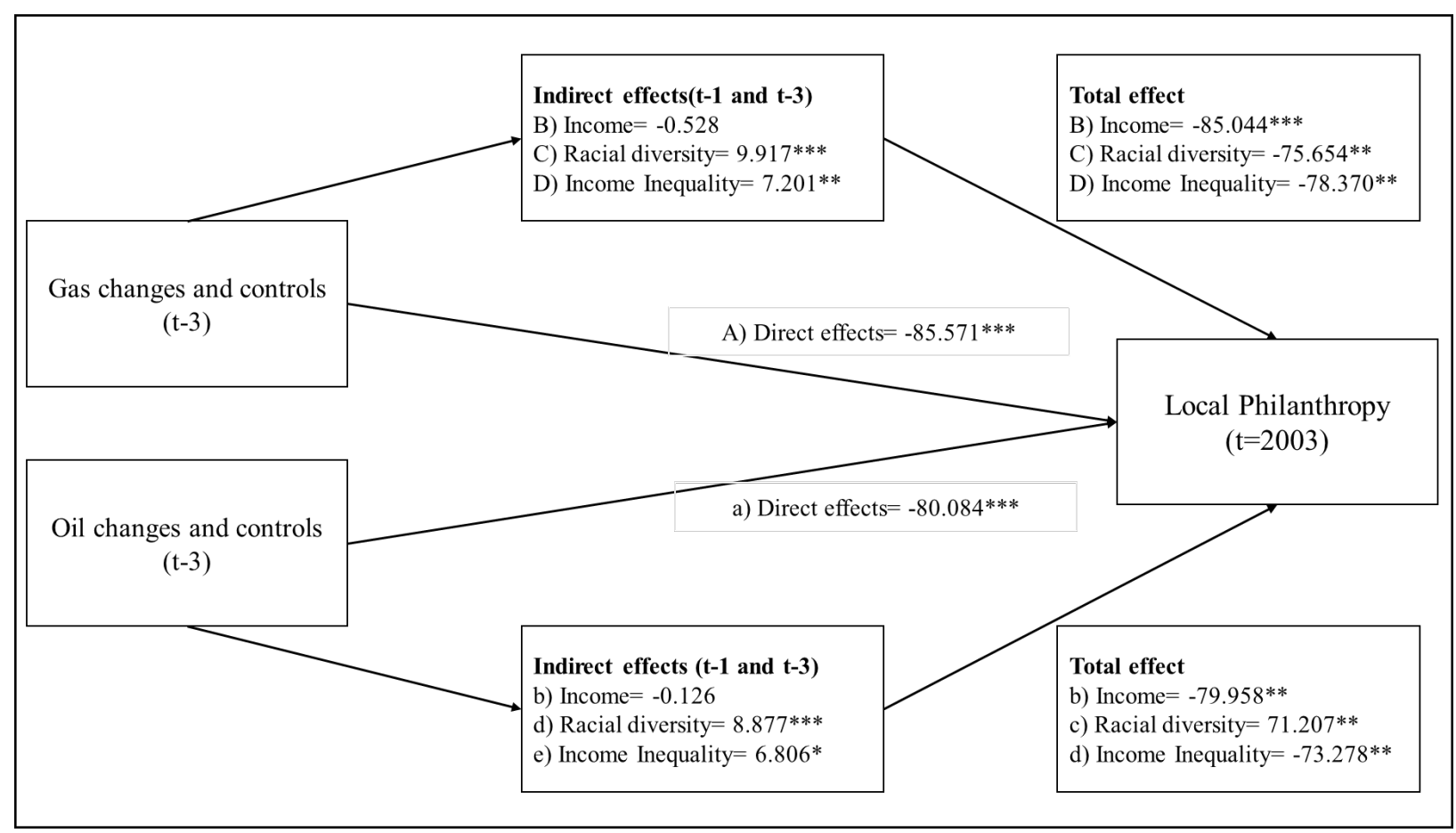




\section{TABLES}

\section{Table 1 Data overview}

\begin{tabular}{|c|c|c|c|}
\hline Variable operationalization & Type & Source & Variable transformation \\
\hline Contribution to nonprofits & Dependent & NCCS & - Per capita (divided by population / \$) \\
\hline Median Household Income & Mediator & Census & - Divided by 1,000 \\
\hline Population change & Mediator & Census & - Ratio of population growth \\
\hline Community racial diversity & Mediator & Census & - Racial diversity index from 0 to 1 \\
\hline Income inequality & Mediator & Census & - Gini coefficient from 0 to 1 \\
\hline Oil production change & Independent & USDA & - Polychotomous variable from 0 to 2 \\
\hline Gas production change & Independent & USDA & - Polychotomous variable from 0 to 2 \\
\hline Urbanity & Control & Census & - Dichotomous variable from 0 to 1 \\
\hline Density of nonprofits & Control & NCCS & - Per capita (divided by population) \\
\hline
\end{tabular}


Table 2 A summary of descriptive statistics

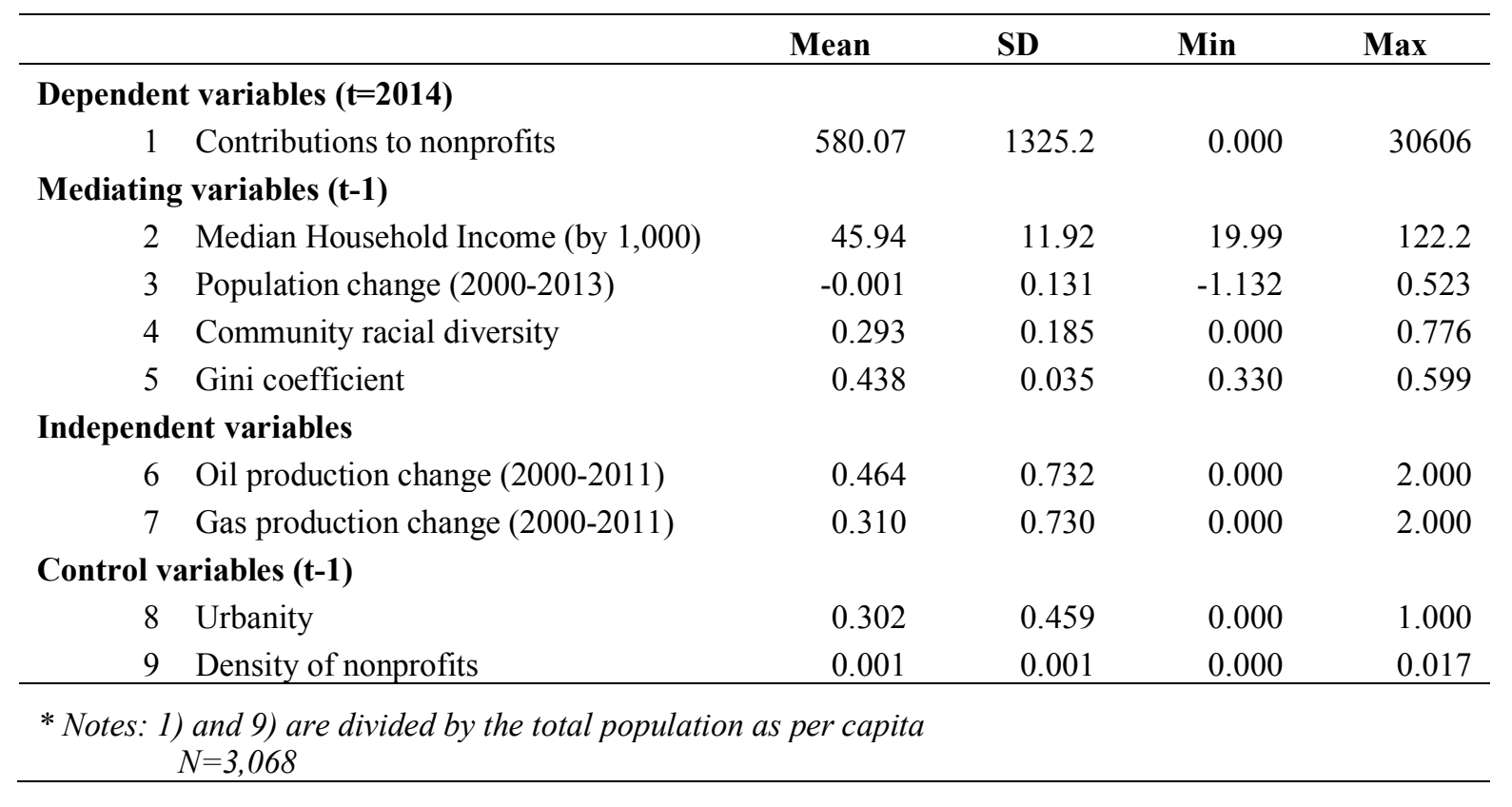


Table 3 Mediation analysis of regression in 2014: oil production change

\begin{tabular}{|c|c|c|c|c|c|}
\hline VARIABLES & $\begin{array}{l}\text { Model 1-1 } \\
\text { Income }\end{array}$ & $\begin{array}{l}\text { Model 1-2 } \\
\text { Pop change }\end{array}$ & $\begin{array}{c}\text { Model 1-3 } \\
\text { Diversity }\end{array}$ & $\begin{array}{l}\text { Model 1-4 } \\
\text { Inequality }\end{array}$ & $\begin{array}{l}\text { Model 1-5 } \\
\text { Philanthropy }\end{array}$ \\
\hline Oil change (00-11) & $\begin{array}{c}0.333 \\
(0.226)\end{array}$ & $\begin{array}{c}-0.0164 * * * \\
(0.00267)\end{array}$ & $\begin{array}{c}0.00308 \\
(0.00412)\end{array}$ & $\begin{array}{c}0.00251^{* * *} \\
(0.000718)\end{array}$ & $\begin{array}{c}-63.86^{* *} \\
(26.48)\end{array}$ \\
\hline Median Household Income (t-1) & & $\begin{array}{r}0.00363 * * * \\
(0.000204)\end{array}$ & $\begin{array}{c}0.00153 * * * \\
(0.000328)\end{array}$ & $\begin{array}{c}-0.00130 * * * \\
(5.24 e-05)\end{array}$ & $\begin{array}{c}13.06^{* * *} \\
(2.115)\end{array}$ \\
\hline Population change (00-13) & $\begin{array}{c}25.83 * * * \\
(1.451)\end{array}$ & & $\begin{array}{c}0.0902 * * * \\
(0.0277)\end{array}$ & $\begin{array}{c}-0.0151^{* * *} \\
(0.00484)\end{array}$ & $\begin{array}{l}-156.3 \\
(178.3)\end{array}$ \\
\hline Racial diversity (t-1) & $\begin{array}{c}4.615^{* * *} \\
(0.989)\end{array}$ & $\begin{array}{c}0.0382 * * * \\
(0.0117)\end{array}$ & & $\begin{array}{c}0.0609 * * * \\
(0.00296)\end{array}$ & $\begin{array}{c}580.0 * * * \\
(116.1)\end{array}$ \\
\hline Gini coefficient (t-1) & $\begin{array}{c}-128.5 * * * \\
(5.190)\end{array}$ & $\begin{array}{c}-0.210 * * * \\
(0.0673)\end{array}$ & $\begin{array}{c}2.000 * * * \\
(0.0970)\end{array}$ & & $\begin{array}{c}6,750 * * * \\
(665.1)\end{array}$ \\
\hline Nonprofit density (t-1) & $\begin{array}{c}3,540 * * * \\
(183.6)\end{array}$ & $\begin{array}{c}-28.79 * * * \\
(2.246)\end{array}$ & $\begin{array}{c}-28.03 * * * \\
(3.505)\end{array}$ & $\begin{array}{c}7.149 * * * \\
(0.604)\end{array}$ & $\begin{array}{c}550,645 * * * \\
(22,749)\end{array}$ \\
\hline Urbanity & $\begin{array}{c}7.296^{* * *} \\
(0.399)\end{array}$ & $\begin{array}{c}0.0697 * * * \\
(0.00482)\end{array}$ & $\begin{array}{c}0.0696 * * * \\
(0.00755)\end{array}$ & $\begin{array}{c}0.0138 * * * \\
(0.00131)\end{array}$ & $\begin{array}{c}282.5^{* * *} \\
(49.18)\end{array}$ \\
\hline Constant & $\begin{array}{c}93.99 * * * \\
(2.181)\end{array}$ & $\begin{array}{c}-0.0632 * \\
(0.0328)\end{array}$ & $\begin{array}{c}-0.644 * * * \\
(0.0490)\end{array}$ & $\begin{array}{l}0.466^{* * *} \\
(0.00252)\end{array}$ & $\begin{array}{c}-3,908 * * * \\
(323.4)\end{array}$ \\
\hline $\begin{array}{l}\text { Observations } \\
\text { R-squared }\end{array}$ & $\begin{array}{l}3,069 \\
0.413\end{array}$ & $\begin{array}{l}3,069 \\
0.300\end{array}$ & $\begin{array}{l}3,069 \\
0.199\end{array}$ & $\begin{array}{l}3,069 \\
0.306\end{array}$ & $\begin{array}{l}3,068 \\
0.270\end{array}$ \\
\hline
\end{tabular}


Table 4 Mediation analysis of regression in 2014: gas production change

\begin{tabular}{|c|c|c|c|c|c|}
\hline VARIABLES & $\begin{array}{c}\text { Model 2-1 } \\
\text { Income }\end{array}$ & $\begin{array}{l}\text { Model 2-2 } \\
\text { Pop change } \\
\end{array}$ & $\begin{array}{c}\text { Model 2-3 } \\
\text { Diversity }\end{array}$ & $\begin{array}{l}\text { Model 2-4 } \\
\text { Inequality }\end{array}$ & $\begin{array}{c}\text { Model 2-5 } \\
\text { Philanthropy }\end{array}$ \\
\hline Gas change (00-11) & $\begin{array}{l}0.0176 \\
(0.227)\end{array}$ & $\begin{array}{c}-0.00958 * * * \\
(0.00269)\end{array}$ & $\begin{array}{c}0.00347 \\
(0.00412)\end{array}$ & $\begin{array}{c}0.00272 * * * \\
(0.000718)\end{array}$ & $\begin{array}{c}-68.15 * * \\
(26.48)\end{array}$ \\
\hline Median Household Income (t-1) & & $\begin{array}{c}0.00363 * * * \\
(0.000205)\end{array}$ & $\begin{array}{r}0.00154 * * * \\
(0.000328)\end{array}$ & $\begin{array}{c}-0.00129 * * * \\
(5.24 e-05)\end{array}$ & $\begin{array}{c}12.94 * * * \\
(2.114)\end{array}$ \\
\hline Population change (00-13) & $\begin{array}{c}25.60 * * * \\
(1.447)\end{array}$ & & $\begin{array}{c}0.0894 * * * \\
(0.0276)\end{array}$ & $\begin{array}{c}-0.0158 * * * \\
(0.00482)\end{array}$ & $\begin{array}{l}-138.1 \\
(177.6)\end{array}$ \\
\hline Racial diversity (t-1) & $\begin{array}{c}4.637 * * * \\
(0.989)\end{array}$ & $\begin{array}{c}0.0382 * * * \\
(0.0118)\end{array}$ & & $\begin{array}{l}0.0609 * * * \\
(0.00296)\end{array}$ & $\begin{array}{c}580.7 * * * \\
(116.1)\end{array}$ \\
\hline Gini coefficient $(t-1)$ & $\begin{array}{c}-128.1 * * * \\
(5.197)\end{array}$ & $\begin{array}{c}-0.222 * * * \\
(0.0676)\end{array}$ & $\begin{array}{c}1.999 * * * \\
(0.0971)\end{array}$ & & $\begin{array}{c}6,765 * * * \\
(665.2)\end{array}$ \\
\hline Nonprofit density (t-1) & $\begin{array}{c}3,515 * * * \\
(183.7)\end{array}$ & $\begin{array}{c}-28.35 * * * \\
(2.255)\end{array}$ & $\begin{array}{c}-28.02 * * * \\
(3.501)\end{array}$ & $\begin{array}{c}7.140 * * * \\
(0.604)\end{array}$ & $\begin{array}{c}550,809^{* * *} \\
(22,726)\end{array}$ \\
\hline Urbanity & $\begin{array}{c}7.284 * * * \\
(0.399)\end{array}$ & $\begin{array}{r}0.0709^{* * *} * \\
(0.00483)\end{array}$ & $\begin{array}{r}0.0696^{* * *} \\
(0.00755)\end{array}$ & $\begin{array}{l}0.0137 * * * \\
(0.00131)\end{array}$ & $\begin{array}{c}284.0^{* * * *} \\
(49.15)\end{array}$ \\
\hline Constant & $\begin{array}{c}93.99 * * * \\
(2.182)\end{array}$ & $\begin{array}{l}-0.0622 * \\
(0.0329)\end{array}$ & $\begin{array}{c}-0.644 * * * \\
(0.0490)\end{array}$ & $\begin{array}{l}0.466 * * * \\
(0.00253)\end{array}$ & $\begin{array}{c}-3,909 * * * \\
(323.3)\end{array}$ \\
\hline $\begin{array}{l}\text { Observations } \\
\text { R-squared }\end{array}$ & $\begin{array}{l}3,069 \\
0.413\end{array}$ & $\begin{array}{l}3,069 \\
0.294\end{array}$ & $\begin{array}{l}3,069 \\
0.199\end{array}$ & $\begin{array}{l}3,069 \\
0.306\end{array}$ & $\begin{array}{l}3,068 \\
0.271\end{array}$ \\
\hline Note: Standard errors in parentl & $\frac{0.415}{s * * * p<0}$ & $\frac{0.294}{* * p<0.05}$ & $\frac{0.199}{0.1}$ & & \\
\hline
\end{tabular}

